\title{
Plant Species Composition and the Perception of the Afforestation in Urban Public Green Spaces in a Municipality in Eastern Brazilian Amazon
}

\author{
Ediane Bó dos Santos, Fernanda Mayara Nogueira (iD) and Dávia Marciana Talgatti *(D)
}

check for

updates

Citation: dos Santos, E.B.; Nogueira, F.M.; Talgatti, D.M. Plant Species Composition and the Perception of the Afforestation in Urban Public Green Spaces in a Municipality in Eastern Brazilian Amazon. Sustainability 2021, 13, 10332. https:// doi.org/10.3390/su131810332

Academic Editor: Sharif

Ahmed Mukul

Received: 3 July 2021

Accepted: 6 September 2021

Published: 16 September 2021

Publisher's Note: MDPI stays neutral with regard to jurisdictional claims in published maps and institutional affiliations.

Copyright: (c) 2021 by the authors. Licensee MDPI, Basel, Switzerland. This article is an open access article distributed under the terms and conditions of the Creative Commons Attribution (CC BY) license (https:/ / creativecommons.org/licenses/by/ $4.0 /)$.

\author{
Laboratório de Algas e Plantas da Amazônia (LAPAM), PPG Biociências, Universidade Federal do Oeste do Pará, \\ UFOPA-Campus de Oriximiná, 68270-000 Oriximiná, PA, Brazil; edianeboh@gmail.com (E.B.d.S.); \\ fer.m.nogueira@hotmail.com (F.M.N.) \\ * Correspondence: davia.talgatti@ufopa.edu.br
}

\begin{abstract}
The plant composition is a fundamental element in public green spaces, improving the environment and people's quality of life. The executing of floristic inventories can contribute to better understanding and management of these spaces. Here, we sought to know the plants used in the afforestation of the main public green spaces in the town of Oriximiná, eastern Brazilian Amazon, as well as to perform a brief analysis of the population's perception regarding the afforestation of these environments. The plants were collected and identified using specific literature and dichotomous keys, in addition to consultations in virtual herbariums. The analysis of the population's perception took place through interviews, with questionnaires collected in each public green space. We registered 1616 individuals from the flora of the squares, distributed in 16 families, 24 genera, and 28 species. Exotic plants are predominant in number species and of individuals. The interviewees demonstrated that they are aware of the importance of plants in the squares and providing shade stands out as the most cited benefit. The afforestation of the squares shows some irregularities, highlighting the need for better planning which includes the use of native species and the participation of the local community in the management of these green areas. Finally, we provide a list of native species, naturally occurring in the Amazon region, that can be used in urban afforestation.
\end{abstract}

Keywords: urban green areas; urban planning; native plants; environmental perception; lower Amazon; urban ecosystems; urban biodiversity

\section{Introduction}

Urbanization promotes changes in green spaces, producing significant impacts on the natural environment, such as loss of biodiversity and ecosystem services [1-4], which will likely be intensified year by year, as with high rates of urban sprawl; $68 \%$ of the world's population is expected to live in urban areas by 2050 [5]. Trees have multiple roles in cities, not only for landscape purposes but also due to their importance in high carbon storage and sequestration rates. [6-8]. In the United States, the carbon storage rate in urban trees was estimated at 643 million tons and the annual sequestration at 25.6 million [8]. In tropical forests, such as the Atlantic Forest, the carbon accumulation in restoration areas shows that, in immature forests, there is a reduced number of large trees responsible for the largest carbon stocks, and highlights the importance of long-time ecological restoration projects to keep the carbon sequestration rates [9,10]. Furthermore, the presence of urban trees improves air quality by removing pollution, influencing the regulation of the urban microclimate, maintaining thermal comfort, and, also, these spaces hold cultural services, producing positive attitudes toward mental health, helping to reduce physiological stress, and providing well-being to the visitors, mainly due to their biodiversity $[5,7,10-13]$.

Urban green space ensures the local biodiversity and provides an opportunity for citizen connect with the surrounding nature. Therefore, a key challenge for these places is 
to link human perception and needs with the ecological balance for preserving biodiversity [14]. Conservation of urban green spaces is a well-recognized alternative to increase the quality of the urban environment, improving the health and well-being of the population [15], in addition to the conservation of biodiversity [16,17]. Besides this, the integration of green spaces can be considered an advance towards sustainable cities, and its access is a matter of environmental justice [18,19]. From this standpoint, the role of municipal and state management comprises the search for strategies to mitigate the negative effects of an increasingly urbanized world, and the planning and management of cultivated plants is an essential step to providing a high-quality and well-designed urban green space [20,21].

The Neotropical region features the greatest biodiversity richness in the world [22,23], and the Amazon region is the most important source of such biodiversity [23]; however, there are still insufficient studies involving urban green areas in the Amazon region. The carrying out of inventories of flora in these environments is the first step to understanding the composition of the urban greening. Recurs in the literature that the urban green spaces are composed mainly of non-native plants [24], and even in megadiversity locations there is a replacement of native plants by non-native plants [24-26]. In this sense, the choice of the cultivated plants is an important step in planning and management of urban green space [27], contributing to the conservation of native biodiversity, connecting citizens with surrounding nature, and also avoiding the spread of invasive species [16,25].

In one survey about urban forestry, realized by Vieira and Panagopoulos [28], the authors registered 43 scientific articles which were carried out in 29 cities in the nine states of the Brazilian Amazon. However, in Pará state only 13 studies in seven cities were realized, pointing out the need for more research on this topic, bearing in mind that the state of Para is the second largest in the Brazilian Amazon and the state that has the largest number of cities. In addition, Brazil, despite being one of the largest countries on the American continent and presenting a great diversity of habitats, is little considered in studies on urban afforestation and Urban Heat Island (UHI) [13,29].

Considering the gap of knowledge about urban green areas in the Amazon region, the importance of the knowledge and maintenance of Brazilian native biodiversity, and the benefits that these areas provide, this study aimed to collect floristic data from the main public areas in the municipality of Oriximiná, Pará (Eastern Brazilian Amazon) along with a brief analysis of the population's perception concerning the afforestation of these environments. In addition, this study presents a list of native species, naturally occurring in the Amazon region, that can be used in urban afforestation.

\section{Materials and Methods}

\subsection{Characterization of the Study Area}

The municipality of Oriximina is located in the Brazilian biome Amazon, more specifically in Western Pará State $\left(01^{\circ} 46^{\prime} 00^{\prime \prime} \mathrm{S}\right.$ and $55^{\circ} 51^{\prime} 30^{\prime \prime} \mathrm{W}$ ) (Figure 1). It is the second-largest municipality in the State of Pará and the fourth of Brazil in territorial extension, covering an area of $107,603.436 \mathrm{~km}^{2}$, and with an estimated population of 73,096 inhabitants. It also has $32 \%$ of urban households on public streets with afforestation [30]. The Oriximiná city holds several protected areas, where $96.82 \%$ of its area is formed by indigenous lands, quilombola territories, and state and federal nature reserves [31]. 


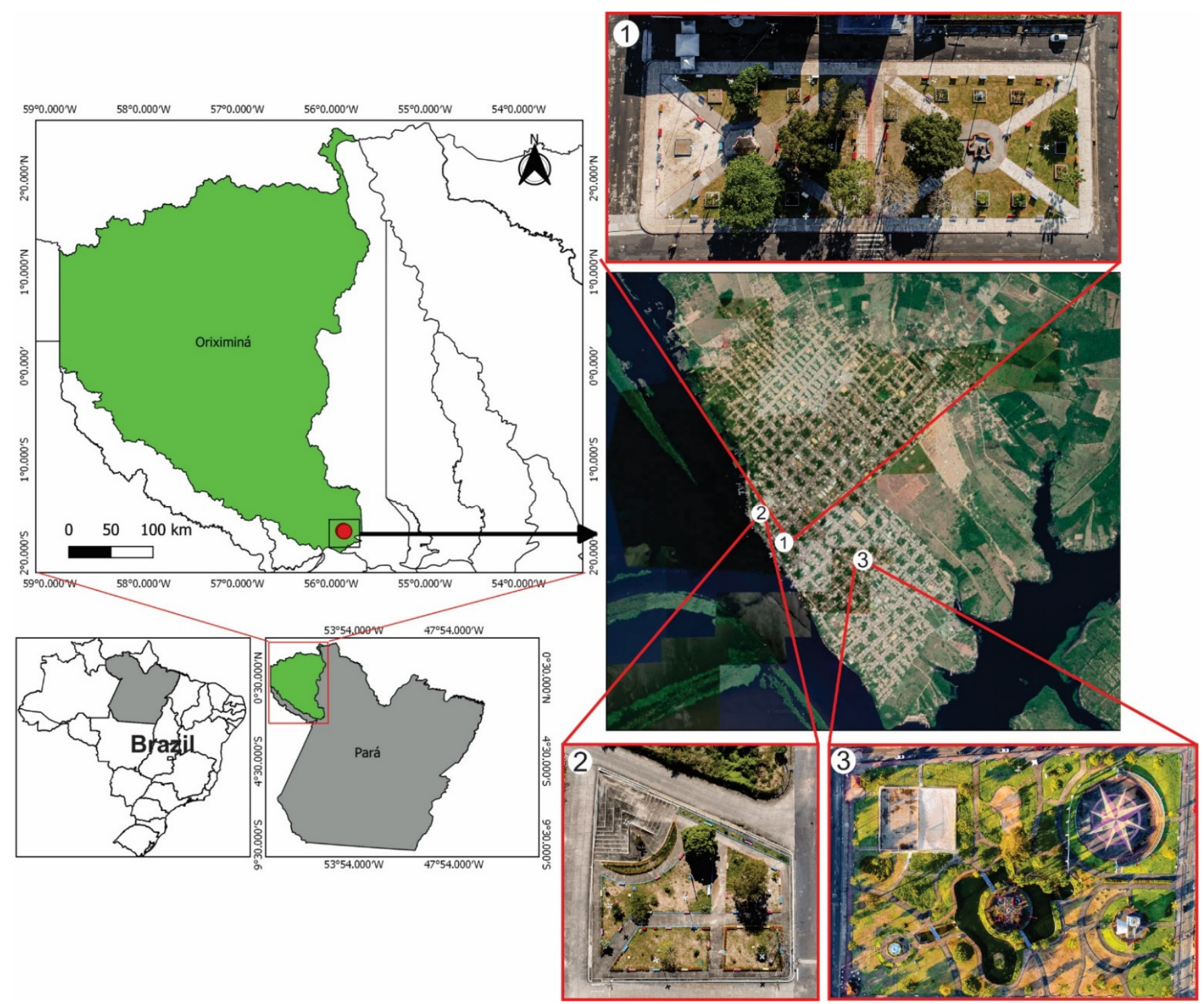

Figure 1. Location of the municipality of Oriximiná, Pará, and the squares studied: (1) Santo Antônio, (2) Saudade Square Square, and (3) Centenario Square.

The study was carried out from May 2018 to July 2019, in three public green spaces in the urban perimeter: Centenario Square, Santo Antônio Square, and Saudade Square. These green spaces were installed at the same time as the official foundation of the municipality, in 1933. These places receive public and cultural festivities that are held annually, such as the Sírio of Santo Antônio, artistic performances by traditional populations, such as indigenous peoples, and quilombolas. In addition, gastronomic events and June parties are held. Therefore, these areas were selected because they represent the main cultural points and most visited public spaces in the city. Table 1 shows information about the area and geographic localization.

Table 1. Total area and geographical coordinates of each urban green space studied in the city of Oriximiná, Pará.

\begin{tabular}{ccc}
\hline Public Green Space & Area $\left(\mathbf{m}^{2}\right)$ & Coordinates \\
\hline Centenário & $25,381.83 \mathrm{~m}^{2}$ & $1^{\circ} 46^{\prime} 10.5^{\prime \prime} \mathrm{S} 55^{\circ} 51^{\prime} 32.9^{\prime \prime} \mathrm{W}$ \\
Santo Antônio & $3841.14 \mathrm{~m}^{2}$ & $1^{\circ} 46^{\prime} 03.5^{\prime \prime} \mathrm{S} 55^{\circ} 52^{\prime} 05.2^{\prime \prime} \mathrm{W}$ \\
Saudade & $1822.99 \mathrm{~m}^{2}$ & $1^{\circ} 45^{\prime} 51.9^{\prime \prime} \mathrm{S} 55^{\circ} 52^{\prime} 15.0^{\prime \prime} \mathrm{W}$ \\
\hline
\end{tabular}




\subsection{Collection and Identification of Botanical Material}

In the floristic data collection, all trees, small trees, palms, vines, and shrubs present in the public green spaces are considered. The known species were identified in loco and, when necessary, the collection of fertile individuals (with flower and/or fruit) and infertile individuals was carried out using basic techniques of collection and herborization for later identification [32]. In the laboratory, these species were identified using stereomicroscope $\left(\right.$ Leica ${ }^{\circledR}$ ) identification keys contained in classical references of Brazilian Flora [33-38]. The record of the information on the collected plants was made using a digital camera and a field notebook containing essential data such as collector, number and date of collection, the characteristics of the environment, and description of the plant (habit, size, leaves, flowers, and fruits). To perform a quantitative analysis, we recorded the number of individuals from each of the registered species. For numerous and dense shrubs, such as the species Ixora coccinea $\mathrm{L}$., we established a different counting criterion. A tape measure was used to delimit a small portion of the area occupied by a given species, with $1 \mathrm{~m}^{2}$ being the standard measure. The individuals present in that area were quantified and, after having obtained the total measurements for the entire area, we estimated the total number of individuals of the species under analysis, which were counted only for the total and not included in the frequency calculations.

The identifications took place according to the Angiosperm Phylogeny Group IV [39] classification system, checked in the database of the Botanical Garden of Rio de Janeiro [40] and Flora do Brasil 2020. Additionally, scientific articles published in journals, monographs, and floras in this area of research were consulted. The names of the species were confirmed on the IPNI and Flora do Brasil 2020 website [41,42]. Regarding taxa where the specific epithet was not possible to determine, identification was restricted to the genus.

The sampled species are classified according to their origin: native and exotic. Those that occur naturally within the Brazilian territory are considered native species, whereas those that are introduced, coming from other countries, are considered exotic. We also categorized species that naturally occur in the Amazon biome and species that naturally do no occur in the Amazon biome, according to Flora do Brasil (2020). We verified both the invasive and toxic potentials of the sampled plants according to the Hórus Institute database and the National System of Toxic-Pharmacological Information (SINITOX), respectively $[43,44]$. The exsiccates are deposited at the HSTM, Herbarium of Universidade Federal do Oeste do Pará, (UFOPA) in Santarém, Pará State, Brazil.

The data were plotted and represented graphically in spreadsheets using Microsoft Office Excel ${ }^{\circledR}$. The relative frequency was calculated by dividing the number of individuals of a given species by the total number of individuals of all species in each urban public green space and then multiplied by one hundred. This study presents a list of native species, naturally occurring in the Amazon region, that can be used in urban afforestation in the municipality of Oriximiná, PA (Table 4). The species were selected based both on the list suggested by Lorenzi (2009) [34] and the work Plants from Amazônia [45], and also consulting Thesis and Monographies of Amazon species, considering the use of plants that are adaptable to the urban environment $[34,45,46]$.

\subsection{Perception of Squares' Visitors}

The analysis of the local community perception, concerning the afforestation of the studied urban public areas, was carried out through interviews with the regular visitors of these places. The objective of the interviews was to know the visitor's profile, such as age and time when they go to the squares, and their perception of afforestation. The interviewees were randomly approached and, as a criterion, people aged over 15 years old were selected. We applied 30 questionnaires in each square (Supplementary Material S1) at different times and days, and we obtained a total of 90 interviews. Participants were previously informed about the nature of the research and were guaranteed anonymity. Most respondents, equivalent to $47 \%$, are aged between 15 and 25 years old, followed by $22 \%$ aged between 26 to 36 years old and 18\% between 37 to 47 years old. Concerning 
the level of education of the respondents, 31\% have completed high school, $25 \%$ did not complete high school, 16\% did not complete elementary school, $13 \%$ have an incomplete bachelor's degree, and 10\% have a complete bachelor's degree.

The questionnaires were structured with open and closed questions, containing information such as the profile of the interviewees and questions related to afforestation, examining participants' knowledge about the plants grown in these places, their degree of importance, benefits, and whether urban afforestation and/or green areas should be considered a priority investment by local management. The data obtained were tabulated and represented graphically using the Microsoft Excel package.

\section{Results}

\subsection{Floristic Composition in Urban Public Areas}

Regarding the floristic composition of the public areas in the study, we registered a total of 1.616 individuals, distributed in 16 families, 24 genera, and 28 species, among which three were identified only up to the generic level (Table 2). The families that demonstrate the highest species richness are Arecaceae (six), Bignoniaceae (four), Apocynaceae (three), and Fabaceae (three). However, despite having a single species, Rubiaceae is the most representative, totaling $91 \%$ of the sampled individuals. For a more specific analysis of the urban public areas, the Centenary square demonstrates the highest floristic richness, totaling 13 identified species, whereas the Santo Antônio demonstrates the lowest richness, totaling 11 species.

Table 2. Plants used in the afforestation of the three urban public areas in the municipality of Oriximiná, Pará. Centenário (C), Santo Antônio (SA), and Saudade (S). The voucher number refers to the identification of the HSTM herbarium. N = number of individuals sampled by places; $\mathrm{NI}=$ total number of individuals; $\mathrm{RF}=$ relative frequency in $(\%) ; \mathrm{N}=$ native; $\mathrm{E}=$ exotic; NID = Not identified; NEA = native, exotic to Amazon; NE = Not Evaluated; LC = Least Concern; NT = Near Threatened . The calculation of relative frequency was not performed for the species marked with an asterisk $\left(^{*}\right)$.

\begin{tabular}{|c|c|c|c|c|c|c|c|c|c|c|}
\hline \multirow{2}{*}{ Families/Species } & \multirow{2}{*}{ Common Name } & \multirow[b]{2}{*}{ Life Form } & \multirow{2}{*}{$\begin{array}{l}\text { Voucher } \\
\text { HSTM }\end{array}$} & \multicolumn{3}{|c|}{$\mathbf{N}$} & \multirow{2}{*}{ NI } & \multirow{2}{*}{ FR\% } & \multirow{2}{*}{ Origin } & \multirow{2}{*}{ IUCN } \\
\hline & & & & $\mathrm{C}$ & SA & $S$ & & & & \\
\hline $\begin{array}{c}\text { Anacardiaceae } \\
\text { Anacardium occidentale L. } \\
\text { Apocynaceae }\end{array}$ & Cajueiro/Cashew & Tree & 14480 & 01 & 00 & 00 & 01 & 0.68 & $\mathrm{~N}$ & $\mathrm{NE}$ \\
\hline $\begin{array}{l}\text { Allamanda blanchetii } \\
\text { A.DC. }\end{array}$ & $\begin{array}{l}\text { Alamanda } \\
\text { roxa/Purple } \\
\text { Allamanda }\end{array}$ & $\begin{array}{l}\text { Flowering } \\
\text { shrub }\end{array}$ & 14488 & 00 & 00 & 01 & 01 & 0.68 & NEA & $\mathrm{NE}$ \\
\hline Allamanda cathartica L. & $\begin{array}{l}\text { Alamanda/Golden } \\
\text { trumpet }\end{array}$ & $\begin{array}{l}\text { Flowering } \\
\text { shrub }\end{array}$ & 14483 & 00 & 18 & 00 & 18 & 12.33 & $\mathrm{~N}$ & $\mathrm{NE}$ \\
\hline Plumeria pudica Jacq. & $\begin{array}{l}\text { Buquê-de- } \\
\text { noiva/Golden } \\
\text { Arrow }\end{array}$ & $\begin{array}{l}\text { Flowering } \\
\text { shrub }\end{array}$ & 14485 & 00 & 00 & 08 & 08 & 5.48 & $\mathrm{E}$ & $\mathrm{LC}$ \\
\hline \multicolumn{11}{|l|}{ Arecaceae } \\
\hline Caryota urens L. & $\begin{array}{l}\text { Palmeira-rabo- } \\
\text { de- } \\
\text { peixe/Solitary } \\
\text { fishtail palm }\end{array}$ & Palm & - & 00 & 01 & 00 & 01 & 0.68 & $\mathrm{E}$ & NE \\
\hline $\begin{array}{l}\text { Dypsis lutescens (H. } \\
\text { Wendl.) Beentje \& J. } \\
\text { Dransf. }\end{array}$ & $\begin{array}{l}\text { Palmeira areca- } \\
\text { bambu/Areca } \\
\text { palm }\end{array}$ & Palm & - & 00 & 06 & 00 & 06 & 4.1 & $\mathrm{E}$ & NT \\
\hline Euterpe oleracea M art. & $\begin{array}{l}\text { Açaí-do- } \\
\text { pará/Açai } \\
\text { berry }\end{array}$ & Palm & - & 12 & 00 & 00 & 12 & 8.22 & $\mathrm{~N}$ & $\mathrm{NE}$ \\
\hline Mauritia flexuosa L. f. & $\begin{array}{l}\text { Buriti/Moriche } \\
\text { palm }\end{array}$ & Palm & - & 13 & 00 & 00 & 13 & 8.90 & $\mathrm{~N}$ & $\mathrm{NE}$ \\
\hline $\begin{array}{c}\text { Pritchardia pacifica Seem. } \\
\text { \& H. Wendl. }\end{array}$ & $\begin{array}{l}\text { Palmeira-de- } \\
\text { leque/Fiji fan } \\
\text { palm }\end{array}$ & Palm & - & 00 & 01 & 01 & 02 & 1.37 & $\mathrm{E}$ & $\mathrm{NE}$ \\
\hline
\end{tabular}


Table 2. Cont.

\begin{tabular}{|c|c|c|c|c|c|c|c|c|c|c|}
\hline \multirow{2}{*}{ Families/Species } & \multirow{2}{*}{ Common Name } & \multirow[b]{2}{*}{ Life Form } & \multirow{2}{*}{$\begin{array}{l}\text { Voucher } \\
\text { HSTM }\end{array}$} & \multicolumn{3}{|c|}{$\mathbf{N}$} & \multirow{2}{*}{ NI } & \multirow{2}{*}{ FR\% } & \multirow{2}{*}{ Origin } & \multirow{2}{*}{ IUCN } \\
\hline & & & & $\mathrm{C}$ & SA & $S$ & & & & \\
\hline Cycadaceae & & & & & & & & & & \\
\hline Cycas circinalis L. & $\begin{array}{l}\text { Cica/Queen } \\
\text { sago }\end{array}$ & Palm & - & 09 & 02 & 03 & 14 & 9.59 & E & NE \\
\hline $\begin{array}{c}\text { Fabaceae } \\
\text { Andira cf. surinamensis } \\
\text { (Bondt) Splitg. ex } \\
\text { Amshoff }\end{array}$ & $\begin{array}{l}\text { Andira-da- } \\
\text { várzea }\end{array}$ & Tree & 14484 & 02 & 00 & 00 & 02 & 1.37 & $\mathrm{~N}$ & $\mathrm{NE}$ \\
\hline $\begin{array}{l}\text { Clitoria fairchildiana } \\
\text { R.A.Howard }\end{array}$ & Sombreiro & Tree & 14489 & 00 & 00 & 01 & 01 & 0.68 & $\mathrm{~N}$ & NE \\
\hline $\begin{array}{c}\text { Delonix regia (Bojer ex } \\
\text { Hook.) Raf. } \\
\text { Malpighiaceae }\end{array}$ & $\begin{array}{l}\text { Flamboyant/Royal } \\
\text { poinciana }\end{array}$ & Tree & 14482 & 00 & 00 & 01 & 01 & 0.68 & E & $\mathrm{NE}$ \\
\hline $\begin{array}{c}\text { Lophanthera lactescens } \\
\text { Ducke } \\
\text { Malvaceae }\end{array}$ & $\begin{array}{l}\text { Lofântera-da- } \\
\text { amazônia }\end{array}$ & Tree & 14478 & 11 & 00 & 00 & 11 & 7.53 & $\mathrm{~N}$ & $\mathrm{NE}$ \\
\hline $\begin{array}{l}\text { Pseudobombax munguba } \\
\text { (Mart.) Dugand } \\
\text { Meliaceae }\end{array}$ & Munguba & Tree & 14490 & 00 & 00 & 01 & 01 & 0.68 & $\mathrm{~N}$ & $\mathrm{NE}$ \\
\hline $\begin{array}{c}\text { Azadirachta indica A. Juss. } \\
\text { Moraceae }\end{array}$ & Nim/Neem & Tree & 14479 & 14 & 01 & 00 & 15 & 10.27 & $\mathrm{E}$ & $\mathrm{NE}$ \\
\hline Ficus benjamina L. & $\begin{array}{c}\text { Ficus/Weeping } \\
\text { fig }\end{array}$ & Tree & 14493 & 00 & 00 & 02 & 02 & 1.37 & $\mathrm{E}$ & $\mathrm{NE}$ \\
\hline $\begin{array}{c}\text { Myrtaceae } \\
\text { Syzygium malaccense (L.) } \\
\text { Merr. \& L.M. Perry } \\
\text { Nyctaginaceae }\end{array}$ & $\begin{array}{l}\text { Jambeiro/Malay } \\
\text { apple }\end{array}$ & Tree & 14477 & 00 & 00 & 01 & 01 & 0.68 & E & $\mathrm{LC}$ \\
\hline $\begin{array}{l}\text { Bougainvillea sp. } \\
\text { Rubiaceae }\end{array}$ & Buganvílea & Vine & 14474 & 00 & 00 & 00 & 01 & 0.68 & NID & - \\
\hline \multirow[t]{2}{*}{ Ixora coccinea $\mathrm{L}$. } & $\begin{array}{l}\text { Ixora ver- } \\
\text { melha/Jungle } \\
\text { geranium }\end{array}$ & $\begin{array}{l}\text { Flowering } \\
\text { shrub }\end{array}$ & 14481 & 764 & 386 & 320 & 1.47 & * & E & NE \\
\hline & Total & & & 847 & 427 & 342 & 1.616 & 100 & & \\
\hline
\end{tabular}

The relative frequency of plant life table shows that the flowering shrub I. coccinea is predominant in the three public green areas, representing, by itself, about $91 \%$ of all vegetation sampled. However, as previously mentioned, given that the density of the growth habit of this species makes it difficult to distinguish each individual, then its relative frequency was not calculated, as it was considered that the criterion established for counting its individuals was different from the others and could underestimate the results. Among the plant life of the remaining species, trees represent $42 \%$, followed by $34 \%$ palms, $21 \%$ flowering shrubs, and $0.68 \%$ vines.

The most frequent species list is as follows: Handroanthus serratifolius (13.01\%), Allamanda cathartica $(12.33 \%)$, Azadirachta indica $(10.27 \%)$, Cycas circinalis $(9.59 \%)$, and Mauritia flexuosa $(8.90 \%)$. Altogether, these represent $54.1 \%$ of the studied community. We also observed a high number of species with a low rate of occurrence, among which the following stand out: Caryota urens, Handroanthus barbatus, Anacardium occidentale, Delonix regia, Syzygium malaccense, Pseudobombax munguba, Clitoria fairchildiana, Allamanda blanchetti, Handroanthus sp.1, and Bougainvillea sp. All of them have a frequency below 1.0\%. Regarding the relative frequency per public green space, the species $A$. cathartica is the most frequent in Santo Antônio square (43.90\%), while P. pudica (36.36\%) is the most frequent in Saudade square and $A$. indica $(17.07 \%$ ) in Centenario square (Table 3$)$.

Exotic plants are predominant concerning native plants, representing $52 \%$ of the vegetation found in the public areas of Oriximiná (Figure 2). Regarding the number of 
individuals sampled, 1.530 exotic species and 82 native species were registered. The species that were identified only up to the genus level were not evaluated in this classification. Therefore, we do not consider them in this classification. Regarding the public green areas analyzed, only in Centenário square does the number of native species exceed that of exotic species.

Table 3. Analysis of the relative frequency (RF) of species per public green area.

\begin{tabular}{|c|c|c|c|}
\hline \multirow{2}{*}{ Species } & Centenário & Santo Antônio & Saudade \\
\hline & RF\% & RF\% & RF\% \\
\hline Allamanda blanchetii & - & - & 4.55 \\
\hline Allamanda cathartica & - & 43.90 & - \\
\hline Anacardium occidentale & 1.22 & - & - \\
\hline Andira cf. surinamensis & 2.44 & - & - \\
\hline Azadirachta indica & 17.07 & 2.44 & - \\
\hline Bougainvillea sp. & 1.22 & - & - \\
\hline Caryota urens & - & 2.44 & - \\
\hline Clitoria fairchildiana & - & - & 4.55 \\
\hline Cycas circinalis & 10.98 & 4.88 & 13.64 \\
\hline Delonix regia & - & - & 4.55 \\
\hline Dracaena fragans & 4.88 & - & - \\
\hline Dypsis lutescens & - & 14.63 & - \\
\hline Euterpe oleracea & 14.63 & - & - \\
\hline Ficus benjamina & - & - & 9.09 \\
\hline Handroanthus barbatus & 1.22 & - & - \\
\hline Handroanthus serratifolius & 15.85 & 12.2 & 4.55 \\
\hline Handronthus sp.1 & 1.22 & - & - \\
\hline Handronthus sp.2 & - & - & 9.09 \\
\hline Licania tomentosa & - & 4.88 & - \\
\hline Lophanthera lactescens & 13.41 & - & - \\
\hline Mauritia flexuosa & 15.85 & - & - \\
\hline Plumeria pudica & - & - & 36.36 \\
\hline Pritchardia pacifica & - & 2.44 & 4.55 \\
\hline Pseudobombax munguba & - & - & 4.55 \\
\hline Roystonea oleracea & - & 7.32 & - \\
\hline Syzygium malaccense & - & - & 4.55 \\
\hline Terminalia catappa & - & 4.88 & - \\
\hline Total & 100 & 100 & 100 \\
\hline
\end{tabular}

As noted in the Flora do Brasil 2020, 10 of the native species observed in our study are reported in the state of Pará: A. occidentale, A. cathartica, M. flexuosa, E. oleracea, $H$. serratifolius, H. barbatus, A. surinamensis, C. fairchildiana, L. lactescens, and P. munguba, while three are endemic to Brazil: A. blanchetii, L. tomentosa, and L. lactescens. Lophanthera lactescens is endemic to the Amazon region, having confirmed occurrence in the states of Acre, Amazonas, Pará, Roraima, and, possibly, Rondônia. The complete list of Angiosperm species registered in the state of Pará can be viewed on the Flora do Brasil 2020 website, by clicking on the link (http:/ / floradobrasil.jbrj.gov.br/, accessed on 1 July 2020) or by accessing the QR code (Figure S1 of the Supplementary Material).

We also observed the presence of invasive species, namely: C. urens, T. catappa, A. indica, C. fairchildiana, and S. malaccense. Among these, only Nim (A. indica) shows a high potential for invasion, as observed in the database of the Horus Institute. Further, regarding the presence of toxic plants in the studied environments, concerning the 28 species identified, as observed in the SINITOX list, $A$. cathartica was mentioned as one of the most toxic species. 


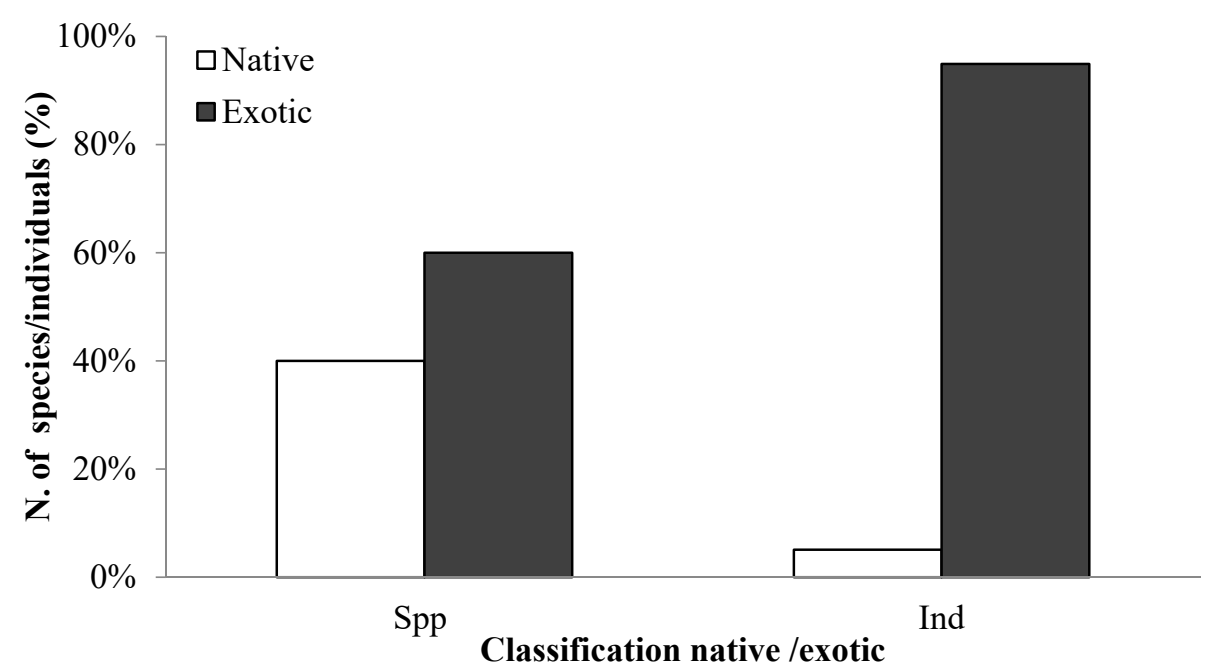

Figure 2. Percentage of species (Spp.) and their individuals (Ind.) found in the public areas of Oriximiná concerning their origin.

\subsection{Analysis of the Questionnaires}

When asked about the afforestation of the squares, $56 \%$ of respondents reported not knowing the plants grown in the locations. On the other hand, $44 \%$ claimed to know at least some of the species. The public green areas were classified as reasonably forested by $43 \%$ of the people interviewed, $39 \%$ considered it good, and $6 \%$ considered the afforestation to be poor.

We observed that the interviewees were aware of the importance of trees in the urban environment. The majority of respondents (97\%) reported that the presence of vegetation in the public areas is very important, whereas $1 \%$ considered it to be of little importance. Regarding the period of when people usually go to these places, it was found that $39 \%$ answered that they usually go at night, 31\% in alternating periods, $19 \%$ in the afternoon, and $11 \%$ in the morning. Some advantages of urban trees are also observed. Most respondents (96\%) report that the trees in the urban environment provide benefits. Shading $(49 \%)$ stands out as the most cited benefit (Figure 3). Besides, $97 \%$ of the interviewees considered that investing in the planning of green spaces should be a priority for the local administration. 


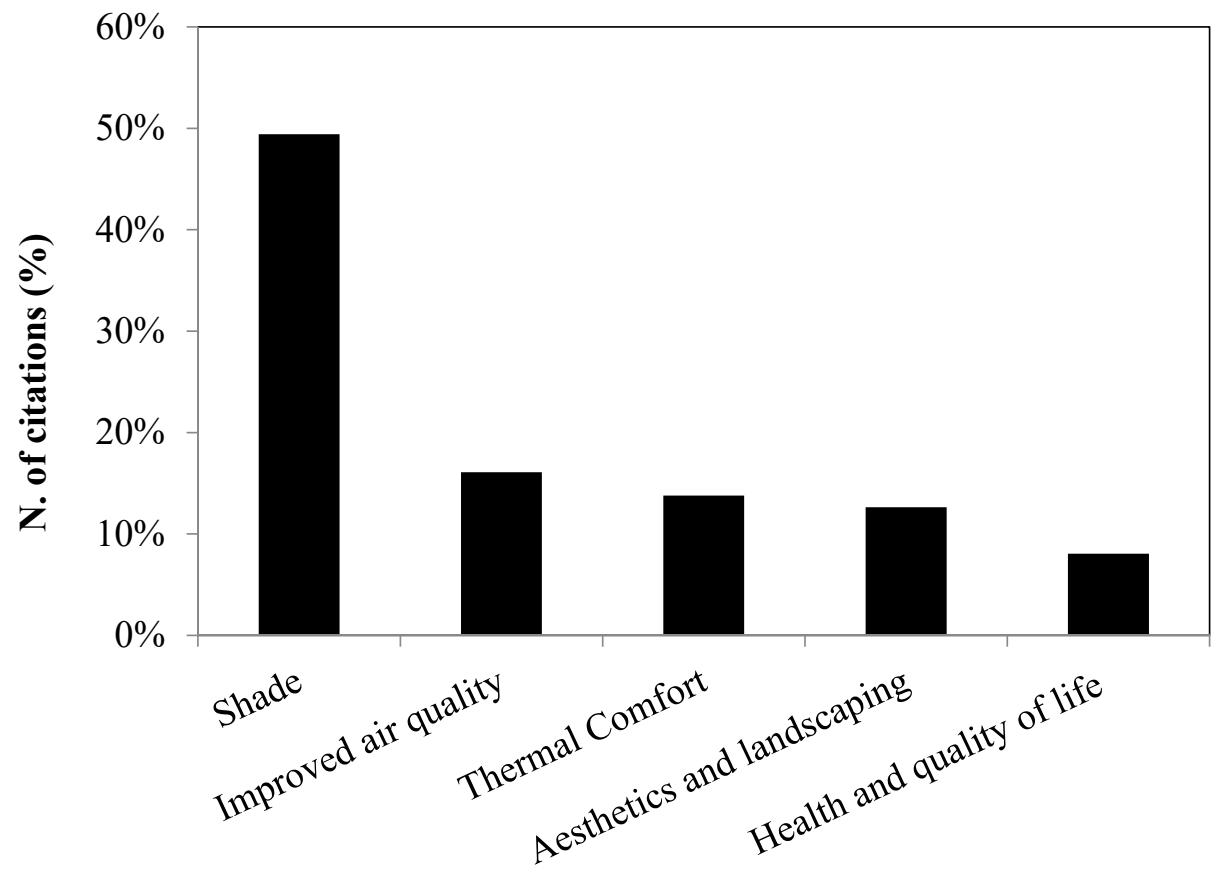

Benefits mentioned

Figure 3. The interviewees' perception of the afforestation benefits in the public green areas.

\section{Discussion}

The floristic richness shown in the three sampled public areas demonstrates similarity when compared to studies developed in other Brazilian small cities. Thirty species were registered in fourteen urban public areas in Altamira, also in the Amazon biome [47], and 29 species were sampled in 9 urban public areas in the city of Areia/PB, in the Atlantic Forest biome [48]. In the same sense, we identified a low species richness and distribution, with the predominance of a single species. Ixora coccinea is predominant in the three public green spaces, representing $91 \%$ of all vegetation sampled. The predominance of a single or few species is recurrent in the literature; in a review of forestry in the Brazilian Amazon, $42 \%$ of the individuals sampled correspond to only three species [28]. In addition to its aesthetic function, the structural complexity of the system is essential for maintaining ecosystem services; therefore, the vegetation present in cities must be as diverse as possible, as this brings a balance and resilience to the urban ecosystem [14,49].

In general, the species $H$. serratifolius and A. cathartica are the most frequent, $13.01 \%$ and $12.33 \%$, respectively. It is recommended to plant no more than $10 \%$ of any species, avoiding any possibility of devastation by pests and diseases [50]. In Centenario square, five species demonstrate frequency above the limit, while three species in Santo Antônio square and two species at Saudade square have the same condition. These irregularities in the distribution of individuals indicate a lack of adequate planning. Indeed, few Brazilian cities have a Municipal Vegetation Policy for Public Spaces (in Portuguese, Sistema Municipal de Áreas Verdes) with regulated environmental legislation [51]. The choice of plants when composing an afforestation plan would be relevant for cities in each region of the country to be able to select the plants in their surroundings and cultivate them preferentially, also considering the local environment and the plant characteristics [52]. This would contribute to rescuing at least part of the biodiversity that existed before the formation of urban spaces and reducing the biotic homogenization [26].

Exotic plants had more species and more individuals when compared with the native ones and, in line with other research carried out in the country involving urban vegetation, most of the plants used in the afforestation of Brazilian cities are exotic [25,51,53,54]. This preference for exotic plants in afforestation in Brazil is related to the arrival of the Portuguese Royal Family during the colonial period (19th century), when many European 
botanists, such as Jean Marie Batiste Glaziou, were brought in to carry out afforestation projects in public places using plants from other continents. In this period, many species were introduced to the country, including I. coccinea [55,56], and this practice of the use of exotic plants has persisted in urban afforestation until nowadays.

In other cities of Brazilian Amazonia, the register of the predominance of exotic plants is very common, as shown by Barros et al. (2018) [57] and Silva et al. (2018) [58] in two municipalities similar to Oriximiná in Pará state. In these studies, more than $65 \%$ of species registered in public areas are exotic. The eminent use of exotic plants in these squares may be associated with the acquisition or unavailability of native seedlings to meet the demand. The availability of exotic species on the market is much higher than native ones, as the latter is difficult to find [25]. Thereby, the occurrence of few native species from the Amazon is justified by the lack of knowledge on our local flora with a potential for use in urban afforestation. There is a consensus in the literature that the lack of natural biodiversity knowledge directly influences the choice of cultivated plants $[16,25,26]$. On the other hand, the cultivation of native plants could be used as an important tool of environmental education with the local community, enhancing the conservation of biodiversity [16].

The invasive and exotic species sampled could also be associated with a lack of knowledge or neglect to investigate their invasive potential, especially when it comes to plants commonly used in afforestation. Rufino et al. (2019) [59] report the lack of knowledge about bioinvasion both by the population and the authorities. The necessary measures have not been taken to prevent the spread of invasive plants. Among the invasive exotic species, the $\operatorname{Nim}(A$. indica) showed high invasive potential. The species is widely cultivated in many Brazilian cities and can reduce biodiversity by suppressing native species, causing ecological and economic impacts [43]. Urban afforestation is considered one of the main routes of introduction and dispersion of invasive exotic species ICMBIO 2019 [60]. Zenni and Ziller [61] registered 117 invasive plants throughout the Brazilian territory. Thus, the ideal scenario consists of investigating potential threats from exotic species before starting any urban afforestation project, thus avoiding possible invasion problems [62].

Also sampled was a species with toxic potential in one of the squares. Although found in a small number, we consider it relevant to investigate the toxic potential of plants before they are used in any landscape projects. It is useful to identify these species, informing the population about health risks. Data available in the National Toxic-Pharmacological Information System registered 821 cases of poisoning by plants, of which $78 \%$ occurred in the urban area, $74 \%$ occurred accidentally, and the majority, 30\%, involved children aged from one to four years old, SINITOX 2020 [44]. In this case, the prevention of these accidents consists mainly of facilitating access to information rather than extinguishing or removing the plants from the environment [63].

To avoid future biodiversity losses in the studied municipality and reducing the use of exotic species in urban afforestation, it would be necessary to know the local flora with potential for the landscape and their characteristics. Besides, there is a need for further research to understand which are the native species that can replace exotic ones in the urban environment, especially those that have been used for centuries [64]. Moreover, it is important to test whether the exclusive use of native species in urban afforestation is necessary to achieve its multiple objectives or functions in the urban environment [65]. With this respect, inventories of urban flora are indispensable for the development of future projects that prioritize both the use of native species and the involvement of the population in the planning of urban green areas.

\section{Perception of Regular Visitors}

The knowledge about community perception can contribute to the planning of green areas in the urban space. It is an instrument to support local environmental management and can be useful to the subsidy for shared management with the participatory involvement of society [66]. The results showed that the interviewees have a positive perception of the 
squares, although most of them do not know the plants grown in these places, much less are they aware of the plants' origins. Nonetheless, it was observed that they are informed of the importance of plants in the urban environment as well as the benefits they provide. Not only by the greenery but by the many benefits associated with biodiversity increase in urban green areas [67].

The most cited benefits are: "shade," "improved air quality," and "thermal comfort"; these three attributes also stand out as the most cited by the assessed the population in the municipality of Santarém and Mocajuba, and also eastern Brazilian Amazon [57,67]. It is common in several perception studies for people to report the "shade" as one of the main functions provided by urban trees. The municipality of Oriximiná has high temperatures, especially during the summer, which may explain this relationship between users and trees, in the search for comfort on hot days, considering that they act in reducing heat and providing a more pleasant environment. Also, perennial species demonstrated to have a greater influence on thermal comfort, especially in the summer, due to the shading they provide [11].

We observed the participation of the surrounding residents in the planting of species in the squares. Although it is a praiseworthy and important attitude for the maintenance of urban vegetation, it can be worrisome when done inappropriately, and it can contribute negatively to the introduction of species unsuitable for cultivation and which may even be exotic with invasive potential. In this context, in addition to including the local population in the planning of green spaces and/or urban afforestation, it is also necessary to promote environmental education actions, especially in primary schools and other education institutes, as well as planting actions and seedling donations by the municipal management. These actions should include informing residents about the relevance of vegetation in the urban environment, especially the importance of native species, as this would prevent disorderly and irregular plantations carried out by the residents themselves. It is significant to emphasize that this awareness of the local population could demand more studies involving biodiversity, specifically in the place where the municipality is inserted [68].

The public green spaces visitations conducted in this study had a curious result. As shown in the answers to the questionnaires, the square's visitors, mainly the local population, usually go at different times of the day to practice physical activities and walks, among others. Visits can serve as an important indicator of the quality of urban green areas and understanding this interaction between users with these environments contributes to better management and planning of these places [69,70]. It is expected that with larger interaction and contact with urban green areas, the greater the benefits will be to its users and that such benefits will vary depending on their biodiversity [69].

\section{Conclusions and Recommendations}

The study's squares showed irregularities, demonstrating the need for better planning. The three squares have a predominance of a single species (I. coccinea) and its prevalence is higher than the recommended limit. As in most Brazilian cities, plants of exotic origin are also predominant in these studied areas, both regarding species and number of individuals. It is important to investigate the invasive potential of exotic species. Therefore, we suggest that management bodies include native species from the Amazon in afforestation projects in relevant municipalities, especially those naturally occurring in the biome to presented better fitness and resilience (see Table 4). It is important to point out that the use of exotic species facilitates the biological invasion process. Therefore, the cultivation of native species in the urban environment serves as a strategy for the maintenance and conservation of our local flora. Management's lack of knowledge of Amazonian flora may limit its use in afforestation. Thus, studies such as this can subsidize future afforestation projects in the municipalities of this region that may support the use of native species and the participation of the local population. Also, it is important to focus on environmental education actions within the community, contributing to improving the quality of the urban environment and stimulating citizens to connect with the natural greenery. Therefore, the weel-planning 
will enhance the effects of vegetation within these urban spaces, especially on the local biodiversity.

Table 4. The suggestion list of native species for use in urban afforestation in Amazonian municipalities.

\begin{tabular}{|c|c|c|c|}
\hline Species & Common Name & Life Form & Família \\
\hline Alibertia edulis (Rich.) A. Rich. & Puru & Tree & Rubiaceae \\
\hline Andira inermis (W.Wright) DC. & Morcegueira/Cabbage tree & Tree & Fabaceae \\
\hline Andira parviflora Ducke & Sucupira-vermelha & Tree & Fabaceae \\
\hline Apeiba tibourbou Aubl. & Pente-de-macaco & Tree & Malvaceae \\
\hline Annona montana Macfad. & Araticum/Mountain soursop & Tree & Annonaceae \\
\hline Bauhinia ungulata L. & Pata-de-vaca & Shrub/Tree & Fabaceae \\
\hline Cenostigma tocantinum Ducke & Pau-pretinho & Shrub/Tree & Fabaceae \\
\hline Costus spiralis (Jacq.) Roscoe & Cana-do-brejo/Spiral ginger & Herb & Costaceae \\
\hline Dipteryx odorata (Aubl.) Willd. & Cumaru/Tonka beans & Tree & Fabaceae \\
\hline Heliconia acuminata L.C.Rich. & Helicônia & Herb & Heliconiaceae \\
\hline Heliconia hirsuta L.f. & Helicônia & Herb & Heliconiaceae \\
\hline Heliconia psittacorum L.f. & $\begin{array}{c}\text { Helicônia-papagaio/Parrot's } \\
\text { beak }\end{array}$ & Herb & Heliconiaceae \\
\hline $\begin{array}{c}\text { Hevea brasiliensis (Willd. ex A.Juss.) } \\
\text { Müll.Arg. }\end{array}$ & Seringueira/Pará rubber tree & Tree & Euphorbiaceae \\
\hline Himatanthus drasticus (Mart.) Plumel & Janaúba, sucuuba & Tree & Apocynaceae \\
\hline Humiria balsamifera (Aubl.) A.St.-Hil. & Umiri & Shrub/Tree & Humiriaceae \\
\hline Inga laurina $(\mathrm{Sw}$.$) Wild$ & Ingá-chichica, ingá-de-macaco & Tree & Fabaceae \\
\hline Inga capitata Desv. & Ingá-ferro & Tree & Fabaceae \\
\hline Inga edulis Mart. & $\begin{array}{l}\text { Ingá-de-metro/Ice-cream- } \\
\text { bean }\end{array}$ & Tree & Fabaceae \\
\hline Jacaranda copaia (Aubl.) D.Don & Caroba & Tree & Bignoniaceae \\
\hline Oenocarpus bacaba Mart. & Bacaba & Palm & Arecaceae \\
\hline Pachira aquatica Aubl. & $\begin{array}{c}\text { Monguba, mamorana/Guiana } \\
\text { chestut }\end{array}$ & Tree & Malvaceae \\
\hline Pouteria ramiflora (Mart.) Radlk. & Abiu-do-campo & Shrub/Tree & Sapotaceae \\
\hline $\begin{array}{c}\text { Tabebuia aurea (Silva Manso) Benth. \& } \\
\text { Hook.f. ex S.Moore }\end{array}$ & $\begin{array}{c}\text { Carobeira, ipê amarelo/Silver } \\
\text { trumpet tree }\end{array}$ & Tree & Bignoniaceae \\
\hline Talisia esculenta (Cambess.) Radlk. & Pitomba & Tree & Sapindaceae \\
\hline
\end{tabular}

Supplementary Materials: The following are available online at https://www.mdpi.com/article/10 .3390/su131810332/s1, Supplementary S1: Questionnaire used in the interviews. Figure S1: Qr code to access the FLORA DO BRASIL 2020 website.

Author Contributions: Conceptualization, E.B.d.S. and D.M.T.; methodology, E.B.d.S.; software, E.B.d.S.; validation, E.B.d.S., D.M.T., F.M.N.; formal analysis, E.B.d.S.; investigation, E.B.d.S.; resources, D.M.T., data curation, E.B.d.S., D.M.T., F.M.N., writing—original draft preparation, E.B.d.S., D.M.T. and F.M.N.; writing-review and editing, E.B.d.S., D.M.T. and F.M.N., visualization, E.B.d.S., D.M.T., F.M.N., supervision, D.M.T., project administration, D.M.T., funding acquisition, D.M.T. All authors have read and agreed to the published version of the manuscript.

Funding: This work was funded by Universidade Federal do Oeste do Pará (UFOPA) (PIBEX/UFOPA undergraduate scholarship to the first author).

Institutional Review Board Statement: Not applicable.

Informed Consent Statement: Not applicable.

Data Availability Statement: Not applicable.

Acknowledgments: The authors thank the Laboratório de Plantas e Algas da Amazônia (LAPAM) of the Universidade Federal do Oeste do Pará (UFOPA) Campus Oriximiná, Secretaria Municipal do Meio Ambiente (SEMMA) of Oriximiná for technical support. We are also grateful to Helison Oliveira, Leilane Vieira, Nilcirene Conceição, Camila Lopes and Melquiades de Oliveira Costa for assisting us in the collection of botanical material.

Conflicts of Interest: The authors declare no conflict of interest. 


\section{References}

1. Zhou, X.; Wang, Y.-C. Spatial-temporal dynamics of urban green space in response to rapid urbanization and greening policies. Landsc. Urban Plan. 2011, 100, 268-277. [CrossRef]

2. Secretariat of the Convention on Biological Diversity. Cities and Biodiversity Outlook-Executive Summary. Montreal. 2012. 16 pages. Available online: https://www.cbd.int/authorities/doc/cbo-1/cbd-cbo1-summary-en-f-web.pdf (accessed on 6 September 2021).

3. Sirakaya, A.; Cliquet, A.; Harris, J. Ecosystem services in cities: Towards the international legal protection of ecosystem services in urban environments. Ecosyst. Serv. 2018, 29, 205-212. [CrossRef]

4. Alberti, M.; Correa, C.; Marzluff, J.M.; Hendry, A.P.; Palkovacs, E.P.; Gotanda, K.M.; Hunt, V.M.; Apgar, T.M.; Zhou, Y. Global urban signatures of phenotypic change in animal and plant populations. Proc. Natl. Acad. Sci. USA 2017, 114, 8951-8956. [CrossRef] [PubMed]

5. United Nations Department of Economic and Social Affairs. United Nations World Urbanization Prospects. The 2018 Revision. Available online: https://www.un.org/development/desa/publications/2018-revision-of-world-urbanization-prospects.html (accessed on 1 July 2020).

6. Nowak, D.J.; Crane, D.E. Carbon storage and sequestration by urban trees in the USA. Environ. Pollut. 2002, 116, 381-389. [CrossRef]

7. Liu, C.; Li, X. Carbon storage and sequestration by urban forests in Shenyang, China. Urban For. Urban Green. 2012, 11, 121-128. [CrossRef]

8. Nowak, D.J.; Hirabayashi, S.; Bodine, A.; Hoehn, R. Modeled PM2.5 removal by trees in ten U.S. cities and associated health effects. Environ. Pollut. 2013, 178, 395-402. [CrossRef]

9. Arcanjo, F.A.; Taglianetti, E.; Torezan, J.M.D. Big trees, big fall: Large-diameter trees and the fate of carbon stocks in Atlantic Forest remnants. Oecologia Aust. 2020, 24, 438-447. [CrossRef]

10. Shimamoto, C.Y.; Botosso, P.C.; Marques, M.C.M. How much carbon is sequestered during the restoration of tropical forests? Estimates from tree species in the Brazilian Atlantic forest. For. Ecol. Manag. 2014, 329, 1-9. [CrossRef]

11. Abreu, L.V.; Labaki, L.C. Conforto térmico propiciado por algumas espécies arbóreas: Avaliação do raio de influência através de diferentes índices de conforto. Ambient. Constr. 2010, 10, 103-117. [CrossRef]

12. Kong, L.; Lau, K.K.-L.; Yuan, C.; Chen, Y.; Xu, Y.; Ren, C.; Ng, E. Regulation of outdoor thermal comfort by trees in Hong Kong. Sustain. Cities Soc. 2017, 31, 12-25. [CrossRef]

13. Li, D.; Liao, W.; Rigden, A.J.; Liu, X.; Wang, D.; Malyshev, S.; Shevliakova, E. Urban heat island: Aerodynamics or imperviousness? Sci. Adv. 2019, 5, eaau4299. [CrossRef]

14. Aronson, M.F.J.; Lepczyk, C.A.; Evans, K.L.; Goddard, M.A.; Lerman, S.B.; MacIvor, J.S.; Nilon, C.H.; Vargo, T. Biodiversity in the city: Key challenges for urban green space management. Front. Ecol. Environ. 2017, 15, 189-196. [CrossRef]

15. World Health Organization (WHO). Urban green spaces: A brief for action. Reg. Off. Eur. 2017, 24. [CrossRef]

16. Dearborn, D.C.; Kark, S. Motivations for conserving urban biodiversity. Conserv. Biol. 2010, 24, 432-440. [CrossRef]

17. Nielsen, A.B.; van den Bosch, M.; Maruthaveeran, S.; van den Bosch, C.K. Species richness in urban parks and its drivers: A review of empirical evidence. Urban Ecosyst. 2014, 17, 305-327. [CrossRef]

18. FAO. Forests and Sustainable Cities; FAO: Rome, Italy, 2018; Volume 69, ISBN 9789251303832.

19. Wolch, J.R.; Byrne, J.; Newell, J.P. Urban green space, public health, and environmental justice: The challenge of making cities 'just green enough'. Landsc. Urban Plan. 2014, 125, 234-244. [CrossRef]

20. Baycan-Levent, T.; Nijkamp, P. Planning and Management of Urban Green Spaces in Europe: Comparative Analysis. J. Urban Plan. Dev. 2009, 135, 1-12. [CrossRef]

21. Govindarajulu, D. Urban green space planning for climate adaptation in Indian cities. Urban Clim. 2014, 10, 35-41. [CrossRef]

22. Antonelli, A.; Sanmartín, I. Why are there so many plant species in the Neotropics? Taxon 2011, 60, 403-414. [CrossRef]

23. Antonelli, A.; Zizka, A.; Carvalho, F.A.; Scharn, R.; Bacon, C.D.; Silvestro, D.; Condamine, F.L. Amazonia is the primary source of Neotropical biodiversity. Proc. Natl. Acad. Sci. USA 2018, 115, 6034-6039. [CrossRef]

24. Gaertner, M.; Wilson, J.R.U.; Cadotte, M.W.; MacIvor, J.S.; Zenni, R.D.; Richardson, D.M. Non-native species in urban environments: Patterns, processes, impacts and challenges. Biol. Invasions 2017, 19, 3461-3469. [CrossRef]

25. Moro, M.F.; Castro, A.S.F. A check list of plant species in the urban forestry of Fortaleza, Brazil: Where are the native species in the country of megadiversity? Urban Ecosyst. 2015, 18, 47-71. [CrossRef]

26. McKinney, M.L. Urbanization as a major cause of biotic homogenization. Biol. Conserv. 2006, 127, 247-260. [CrossRef]

27. Banerjee, A.K.; Dewanji, A. Native exotic relationships in plant communities: The role of exotic dominance in framing community composition. Ecol. Res. 2017, 32, 653-665. [CrossRef]

28. Vieira, T.A.; Panagopoulos, T. Urban Forestry in Brazilian Amazonia. Sustainability 2020, 12, 3235. [CrossRef]

29. Fitria, R.; Kim, D.; Baik, J.; Choi, M. Impact of biophysical mechanisms on Urban Heat Island associated with climate variation and urban morphology. Sci. Rep. 2019, 9, 19503. [CrossRef]

30. Instituto Brasileiro de Geografia e Estatísticas (IBGE). Available online: https://cidades.ibge.gov.br/brasil/pa/oriximina/ panorama (accessed on 22 April 2020).

31. Instituto Socioambiental (ISA). Available online: https://www.socioambiental.org/pt-br/mapas/amazonia-brasileira-2014 (accessed on 1 July 2020). 
32. Peixoto, A.L.; Maia, E.C. Manual de Procedimentos Para Herbários; Editora Universitária UFPE: Recife, Brazil, 2013.

33. Barroso, G.M. Sistemática de Angiospermas do Brasil; Imprensa Universitária: Viçosa, Brazil, 1991.

34. Lorenzi, H. Árvores Brasileiras: Manual de Identificação e Cultivo de Plantas Arbóreas Nativas do Brasil; Instituto Plantarum: Nova Odessa, Brazil, 2009; Volume 3.

35. Lorenzi, H. Árvores Brasileiras: Manual de Identificação e Cultivo de Plantas Arbóreas Nativas do Brasil; Instituto Plantarum: Nova Odessa, Brazil, 1998; Volume 2.

36. Lorenzi, H. Árvores Brasileiras: Manual de Identificação e Cultivo de Plantas Arbóreas Nativas do Brasil; Instituto Plantarum: Nova Odessa, Brazil, 1992; Volume 1.

37. Saueressig, D. Plantas do Brasil—Árvores Nativas; Editora Plantas do Brasil: Irati, Brazil, 2017.

38. Souza, V.C.; Lorenzi, H. Botânica Sistemática: Guia Ilustrado Para Identificação das Famílias de Angiospermas da Flora Brasileira, Baseado em APG II; Instituto Plantarum: Nova Odessa, Brazil, 2005.

39. The Angiosperm Phylogeny Group. APG IV An update of the Angiosperm Phylogeny Group classification for the orders and families of flowering plants: APG IV. Bot. J. Linn. Soc. 2016, 181, 1-20. [CrossRef]

40. JABOT Jardim Botânico do Rio de Janeiro. Available online: http:/ /jabot.jbrj.gov.br (accessed on 1 July 2020).

41. Flora do Brasil 2020 Jardim Botânico do Rio de Janeiro. Available online: http:/ / floradobrasil.jbrj.gov.br/ (accessed on 1 July 2020).

42. IPNI. International Plant Names Index. 2021. Available online: http:/ / www.ipni.org (accessed on 27 July 2021).

43. Instituto Hórus 2020 Base de Dados Nacional de Espécies Exóticas Invasoras em I3N-Brasil. Available online: http://www. institutohorus.org.br/ (accessed on 13 February 2020).

44. SINITOX 2020 Dados de Intoxicações. Dados Nacionais. Available online: https:/ / sinitox.icict.fiocruz.br (accessed on 18 February 2020).

45. da Silva Rios, M.N.; Pastore, F., Jr. Plantas da Amazônia: 450 Espécies de Uso Geral; Universidade de Brasília: Brasília, Brazil, 2011.

46. João, R.A.L.; João, P.d.C.L.; Stoney, D.N.P.; Ary, V.d.P. Germinação de sementes e crescimento inicial de plântulas de ingá-mirimInga laurina (S W.) Willd-Utilizada na arborização urbana de Rio Branco, Acre. Rev. Soc. Bras. Arborização Urbana $2019,7,11$. [CrossRef]

47. Souza, O.P.S.; Souza, P.T.S.; Freitas, A.D.D.; Paraense, V.C.; Silva, S.A.S. Diagnóstico quali-quantitativo da arborização das praças do município de Altamira, Pará. Encicl. Biosfera 2013, 9, 1080.

48. Gomes, A.C.; de Figueredo, L.F.; Souza, J.T.A.; Souto, J.S.; de Lacerda, A.V. Flora of Public Squares in the City of Areia, Paraíba, Brazil. Floresta Ambiente 2019, 26. [CrossRef]

49. Lorenzi, H.; Bacher, L.B.; Torres, M.A. Árvores e Arvoretas Exóticas no Brasil: Madeireiras, Ornamentais e Aromáticas, 1st ed.; Instituto Plantarum de Estudos da Flora: Nova Odessa, Brazil, 2018; ISBN 978-85-86714-56-6.

50. Santamour, F.S. Trees for urban planting: Diversity, Uniformity, and Common Sense. In Proceedings of the Seventh Conference of The Metropolitan Tree Improvement Alliance, Lisle, IL, USA, 11-12 June 1990; Volume 7, pp. 57-65.

51. De Freitas, W.K.; Magalhães, L.M.S.; de Santana, C.A.A.; Pereira Junior, E.R.; de Castro Machado de Souza, L.; Toledo, R.A.B.; Garção, B.R. Tree composition of urban public squares located in the Atlantic Forest of Brazil: A systematic review. Urban For. Urban Green. 2020, 48, 126555. [CrossRef]

52. Asgarzadeh, M.; Vahdati, K.; Lotfi, M.; Arab, M.; Babaei, A.; Naderi, F.; Pir Soufi, M.; Rouhani, G. Plant selection method for urban landscapes of semi-arid cities (a case study of Tehran). Urban For. Urban Green. 2014, 13, 450-458. [CrossRef]

53. de Souza e Silva, J.L.; de Oliveira, M.T.P.; Oliveira, W.; Borges, L.A.; Cruz-Neto, O.; Lopes, A.V. High richness of exotic trees in tropical urban green spaces: Reproductive systems, fruiting and associated risks to native species. Urban For. Urban Green. 2020, 50, 126659. [CrossRef]

54. Oliveira, M.T.P.; Silva, J.L.S.; Cruz-Neto, O.; Borges, L.A.; Girão, L.C.; Tabarelli, M.; Lopes, A.V. Urban green areas retain just a small fraction of tree reproductive diversity of the Atlantic forest. Urban For. Urban Green. 2020, 54, 126779. [CrossRef]

55. Terra, C. OS Jardins do Brasil do Século XIX: Glaziou Revisitado; EBA/UFRJ: Rio de Janeiro, Brazil, 1993.

56. dos Santos, A.R.; da Rocha, C.F.D.; Bergallo, H.G. Native and exotic species in the urban landscape of the city of Rio de Janeiro, Brazil: Density, richness, and arboreal deficit. Urban Ecosyst. 2010, 13, 209-222. [CrossRef]

57. Barros, V.D.S.; Martins, C.M.; Dos Santos, M.A.S.; Rebello, F.K.; Monteiro, C.W.B.; Mesquita, I.S.B. Avaliação da organização árborea e a percepção dos usuários das praças do município de Mocajuba, estado do Pará, Brasil. Rev. Soc. Bras. Arborização Urbana 2019, 13, 1. [CrossRef]

58. Silva, I.D.R.; Oliveira, À.T.D.S.; Da Silva, L.B.O.; Baia, R.S.; Correa, T.B.C.; Martins, W.B.R. Diagnóstico visual e fitossociologia na arborização de praças em Paragominas, Pará. Rev. Soc. Bras. Arborização Urbana 2018, 13, 1. [CrossRef]

59. Rufino, M.R.; Silvino, A.S.; Moro, M.F. Exóticas, exóticas, exóticas: Reflexões sobre a monótona arborização de uma cidade brasileira. Rodriguésia 2019, 70. [CrossRef]

60. ICMBIO. Guia de Orientação Para o Manejo de Espécies Exóticas Invasoras em Unidades Conservação Federais; Instituto Chico Mendes: Brasilia, Brazil, 2019.

61. Zenni, R.D.; Ziller, S.R. An overview of invasive plants in Brazil. Rev. Bras. Botânica 2011, 34, 431-446. [CrossRef]

62. Rodrigues, M.L.; Malheiros, T.F.; Fernandes, V.; Dagostin Darós, T. A percepção ambiental como instrumento de apoio na gestão e na formulação de políticas públicas ambientais. Saúde Soc. 2012, 21, 96-110. [CrossRef]

63. Bochner, R.; Lemos, E. Plantas tóxicas em espaços escolares infantis: Do risco à informação. J. Health NPEPS 2017, 2, 102-112. 
64. Buckeridge, M. Árvores urbanas em São Paulo: Planejamento, economia e água. Estudos Avançados 2015, 29, 85-101. [CrossRef]

65. Oldfield, E.E.; Warren, R.J.; Felson, A.J.; Bradford, M.A. FORUM: Challenges and future directions in urban afforestation. J. Appl. Ecol. 2013, 50, 1169-1177. [CrossRef]

66. Carrus, G.; Scopelliti, M.; Lafortezza, R.; Colangelo, G.; Ferrini, F.; Salbitano, F.; Agrimi, M.; Portoghesi, L.; Semenzato, P.; Sanesi, G. Go greener, feel better? The positive effects of biodiversity on the well-being of individuals visiting urban and peri-urban green areas. Landsc. Urban Plan. 2015, 134, 221-228. [CrossRef]

67. Fongar, C.; Aamodt, G.; Randrup, T.B.; Solfjeld, I. Does perceive green space quality matter? Linking Norwegian adult perspectives on perceived quality to motivation and frequency of visits. Int. J. Environ. Res. Public Health 2019, 16, 2327. [CrossRef]

68. Sartori, R.A.; Martins, G.A.C.; Zaú, A.S.; Brasil, L.S.C. Urban afforestation and favela: A study in a community of Rio de Janeiro, Brazil. Urban For. Urban Green. 2019, 40, 84-92. [CrossRef]

69. Fuller, R.A.; Irvine, K.N.; Devine-Wright, P.; Warren, P.H.; Gaston, K.J. Psychological benefits of greenspace increase with biodiversity. Biol. Lett. 2007, 3, 390-394. [CrossRef]

70. Alves, F.R.N.; de Aquino, M.G.C.; Maestri, M.P.; Tenório, R.S.; das Silva, J.J.N.; Carneiro, F.D.S.; dos Santos, J.L.; de Figueira, E.P.O. Percepção da arborização urbana pelos moradores de duas zonas do município de Santarém (PA). Nat. Conserv. 2019, 12, 60-76. [CrossRef] 